\title{
Struktur Komunitas dan Persentase Penutupan Kanopi Mangrove Pulau Salawati Kabupaten Kepulauan Raja Ampat Provinsi Papua Barat
}

\author{
Joshian Nicolas William Schaduw \\ Fakultas Perikanan dan Ilmu Kelautan,Universitas Sam Ratulangi, Sulawesi Utara, Indonesia.
}

Korespondent E-mail: schaduw@unsrat.ac.id

Diterima: 2018-04-15 /Refisi: 2018-11-26 Disetujui: 2019-03-21

(2019 Fakultas Geografi UGM dan Ikatan Geograf Indonesia (IGI)

\begin{abstract}
Abstrak Mangrove adalah salah satu ekosistem penting yang berada dipulau kecil, perubahan kondisi pada ekosistem ini akan mempengaruhi produktivitas dari ekosistem terkait lainnya seperti padang lamun dan terumbu karang. Penelitian ini bertujuan untuk menganalisa struktur komunitas mangrove dan persentase penutupan kanopi yang ada di Pulau Salawati Kabupaten Kepulauan Raja Ampat, Provinsi Papua Barat. Penelitian ini dilakukan secara berkala dari tahun 2016-2017, monitoring dari struktur komunitas dan persentase penutupan untuk mengetahui pertumbuhan dan tingkat degradasi dari ekosistem mangrove. Metode yang digunakan dalam kajian ini adalah analisa struktur komunitas mangrove dan hemisperichal photography analysis. Hasil penelitian menunjukkan bahwa Pulau Salawati memiliki empat jenis mangrove (Rhizophora mucronata, R. apiculata, Bruguiera gymnorrhiza, Sonneratia alba) dengan kerapatan rata-rata 1254,3 ind/ha, persentase penutupan mangrove rata-rata sebesar 84,14\% tahun 2016 dan 84,73\% tahun 2017 atau meningkat $0,59 \%$. Jenis mangrove yang mendominasi adalah jenis Rhizophora apiculata yang memiliki indeks nilai penting tertinggi. Stasiun 1 di Kampung Wamega mengalami penurunan persentase kanopi mangrove sebesar 8,62\%, yang diakibatkan oleh penebangan pohon mangrove disekitar daerah penelitian. Kondisi kanopi mangrove Pulau Salawati termasuk kategori baik, sedangkan untuk kerapatan rata-rata mangrove di Pulau Salawati masuk dalam kategori padat. Kajian ini penting dilanjutkan secara berkala untuk memonitoring kondisi mangrove yang ada di Pulau Salawati dan pulau lainnya yang memiliki ekosistem mangrove.
\end{abstract}

Kata kunci: Mangrove; Salawati; Struktur Komunitas; Kanopi

\begin{abstract}
Mangroves are one of the important ecosystems located in small islands, changes in conditions in these ecosystems will affect the productivity of other related ecosystems such as seagrass beds and coral reefs. This study aims to analyze the mangrove community structure and the percentage of canopy closure on Salawati Island, Raja Ampat Islands Regency, West Papua Province. This research is conducted regularly from 2016-2017, monitoring of community structure and percentage of closure to determine the growth and degradation rates of mangrove ecosystems. The method used in this study is the analysis of mangrove community structure and hemispherical photography analysis. The results showed that Salawati Island had four mangrove species (Rhizophora mucronata, R. apiculata, Bruguiera gymnorrhiza, Sonneratia alba) with an average density of 1254.3 ind / ha, the average percentage of mangrove cover was $84.14 \%$ in 2016 and $84.73 \%$ in 2017 or an increase of $0.59 \%$. The dominant type of mangrove is Rhizophora apiculata which has the highest important value index. Station 1 in Wamega village has decreased the percentage of mangrove canopy by 8.62\%, which is caused by logging of mangrove trees around the study area. The condition of the Salawati Island mangrove canopy is in a good category, while the average density of mangroves on Salawati Island is in the solid category. This important study is continued regularly to monitor the condition of mangroves on Salawati Island and other islands that have mangrove ecosystems.
\end{abstract}

Keywords: Mangrove; Salawati; Community Structure; Canopy

\section{PENDAHULUAN}

Indonesia adalah negara yang memiliki ekosistem mangrove terbesar di dunia dan Papua Barat adalah Provinsi yang memiliki luasan mangrove terbesar di Indonesia. Data FAO (2007) luas hutan mangrove di Indonesia pada tahun 2005 hanya mencapai 3,062,300 ha atau $19 \%$ dari luas hutan mangrove di dunia di atas Australia (10\%) dan Brazil (7\%). Di tingkat Asia luasan hutan mangrove Indonesia sekitar 49\% dari luas total hutan mangrove di Asia, dikuti oleh Malaysia (10\% ) dan Mnyanmar (9\%). Berbeda dengan data Kementerian Kehutanan 2014 berdasarkan Direktorat Jenderal Bina Pengelolaan DAS dan Perhutanan Sosial luas potensial hutan mangrove Indonesia adalah 3,7 juta Ha dengan luasan yang berkondisi baik 2,67 juta $\mathrm{Ha}$ (71\%), dan kondisi rusak 1,08 juts $\mathrm{Ha}$ (29\%), luasan yang rusak ini terbagi dalam kawasan hutan 324.000 $\mathrm{Ha}(30 \%)$ dan diluar kawasan hutan $756.800 \mathrm{Ha}(70 \%)$.

Ekosistem mangrove adalah ekosistem penting dan berdampak sistemik terhadap ekosistem pesisir lainnya. Konektivitas antar ekosistem pesisir lainnya seperti terumbu karang dan padang lamun dalam hal penyaluran unsur hara, migrasi ontogenik biota, serta penyaring bahan pencemar dari arah darat membuat ekosistem ini memiliki fungsi yang strategis. Hutan mangrove merupakan tipe hutan tropika yang 


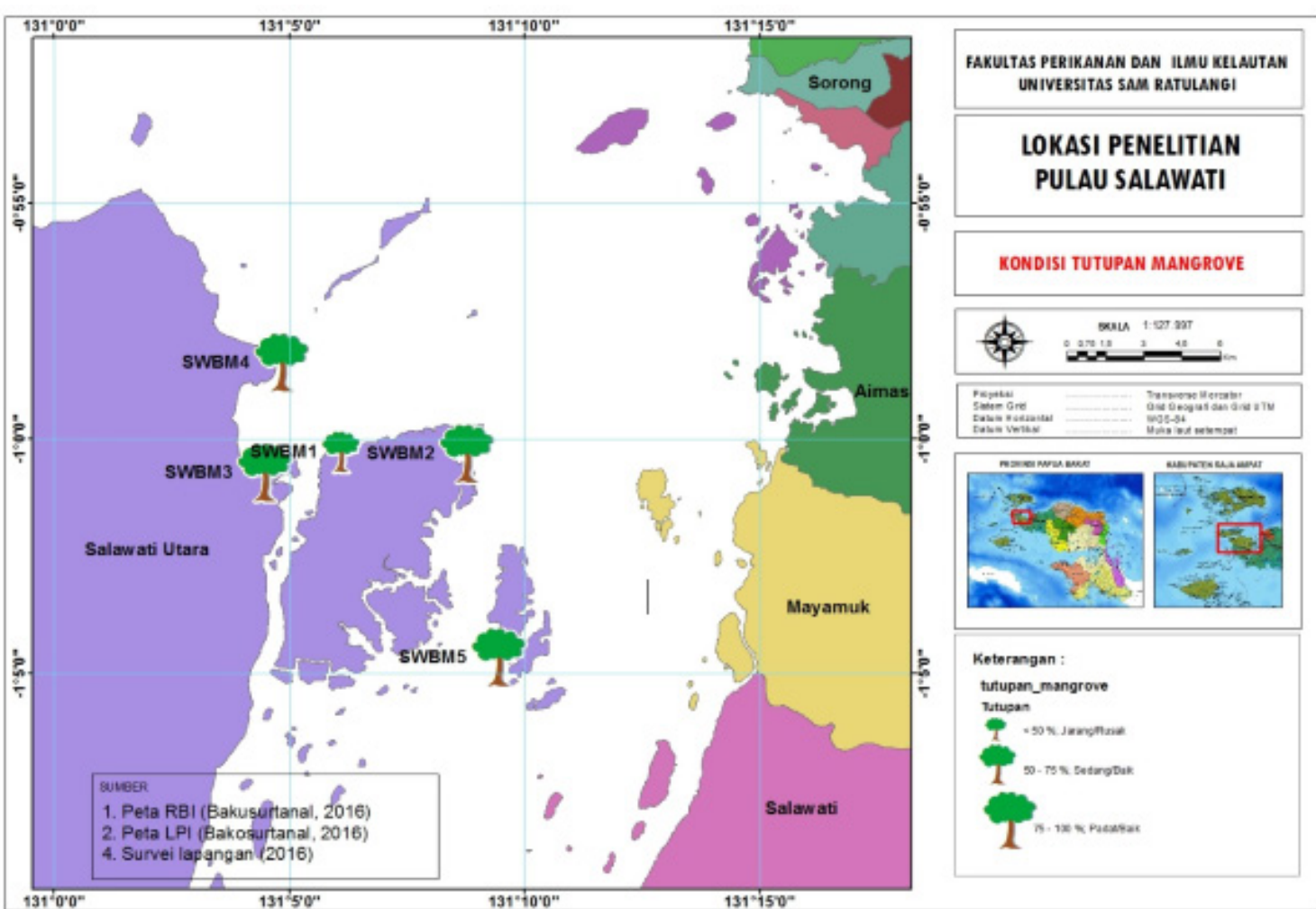

Gambar 1. Peta Lokasi Penelitian

khas tumbuh sepanjang pantai atau muara sungai yang dipengaruhi oleh pasang surut air laut. Hutan mangrove dapat tumbuh dengan baik pada daerah yang memiliki muara sungai yang besar dan delta yang aliran airnya mengandung lumpur. Dilihat dari fungsi bagi ekosistem perairan, hutan mangrove memberikan tempat untuk memijah dan membesarkan berbagai jenis ikan, udang, crustacea dan biota perairan lainnya (Nagelkerken \& Van Der Velde, 2004). Secara umum mangrove merupakan daerah nursery ground, spawning graound, dan feeding ground bagi semua biota yang berasosiasi di dalamnya. Serasah mangrove yang jatuh ke perairan akan diurai oleh mikroorganisme menjadi partikel-partikel detrius sebagai sumber makanan bagi biota perairan yang memiliki perilaku makan dengan menyaring air laut (Alongi et al., 2002; Holmer \& Olsen, 2002). Selain fungsi ekologis, hutan mangrove juga memiliki fungsi ekonomi yang oleh sebagian masyarakat pesisir dilakukan dengan menebang mangrove untuk dimanfaatkan sendiri sebagai kayu bakar dan bahan bangunan atau dijual sebagai kayu bakar dan bahan baku industri, ada juga yang mengkonversi hutan mangrove menjadi tambak (Grasso, 1998). Pemanfaatan jasa ekosistem mangrove yang sedang dikembangkan di Indonesia saat ini adalah mangrove sebagai kawsan ekoswisata, hal ini dirasakan mampu menjawab tantangan pemanfaatan jasa ekosistem yang berbasis konservasi, Desa Bahoi di Sulawesi Utara adalah salah satu desa yang sudah mengembangkan potensi ini dengan melakukan pengelolaan ekosistem mangrove berbasis masyarakat. Komiyama et al. (2008) menyatakan bahwa ekosistem mangrove memiliki peranan yang penting dalam mengurangi efek gas rumah kaca sebagai mitigasi perubahan iklim karena mampu mereduksi $\mathrm{CO} 2$ melalui mekanisme "sekuestrasi", yaitu penyerapan karbon dari atmosfer dan penyimpanannya dalam bentuk biomassa. Selain itu mangrove memiliki kemampuan untuk mengakumulasi logam berat pada daun muda, akar napas, daun tua, cabang dan ranting, walaupun kemampuan mengakumulasi logam berat pada berbagai jenis mangrove berbeda (Setiawan, 2013). Ekosistem mangrove juga dapat dikembangkan melalui mekanisme silvofishery empang parit di lahan mangrove. Keberhasilan silvofishery ditunjukkan dengan meningkatnya berat komoditas yang ada di dalamnya, Kajian Poedjirahajoe (2015) silvofishery dengan komoditas kepiting soka berkembang dengan baik karena habitat yang kondusif bagi kepiting soka untuk hidup dan berkembangbiak.

Memiliki luasan mangrove terbesar di dunia membuat Indonesia mendapat banyak tantangan dalam pengelolaan ekosistem mangrove, pemanfaatan yang bersifat destruktif dan bencana alam membuat ekosistem ini rentan terhadap kerusakan. Noor et al, 2006 menyatakan bahwa penurunan luasan mangrove di Pulau Papua kurun waktu 1986-1990 sebesar 118.000 ha, dari luas awal 1.500 .000 ha menjadi 1.382 .000 ha dalam kurun waktu empat tahun tersebut, hal ini menjadi tantangan terbesar dalam proses konservasi sumberdaya pesisir dan laut saat ini. Penurunan luasan mangrove 7,6\% ini membuat pengambil kebijakan di Indonesia merasa perlu untuk melakukan kajian monitoring dan evaluasi ekosistem pesisir, khususnya ekosistem 
mangrove. Kajian ini bertujuan untuk mengetahui struktur komunitas mangrove dan persentase tutupan kanopi mangrove yang dapat dijadikan indikator dalam mengavaluasi pertumbuhan ataupun kerusakan yang ada pada ekosistem mangrove. Manfaat dari kajian ini adalah dapat memberikan gambaran tentang kondisi existing ekosistem mangrove, tingkat pemanfaatan, dan laju degradasi hutan mangrove secara berkala, hal ini sangat dibutuhkan oleh pengambil kebijakan untuk merumuskan strategi pengelolaan berbasis ekosistem yang terpadu dan berkelanjutan.

\section{METODE PENELITIAN}

\section{Waktu dan tempat penelitian}

Penelitian dilakukan pada hutan mangrove Pulau Salawati, Kabupaten Kepulauan Raja Ampat, Provinsi Papua Barat (Gambar 1). Lokasi penelitian dibagai dalam lima stasiun pengamatan yaitu Kampung Wamega (St.1), Pulau Kasim Kecil (St.2), Kampung Kolobo (St.3), Kampung Samate (St.4), dan Pulau Kabra Kecil (St.5). Kajian ini dilakukan secara berkala dari September 2016 - September 2017.

\section{Pengukuran Struktur Komunitas Mangrove}

Dalam setiap plot, 10x10 m2 dilakukan pengukuran diameter batang pohon (Ashton \& McIntosh, 2002) dengan menggunakan meteran pada variasi letak pengukuran berdasarkan English et al. (1997) dan Keputusan Menteri Lingkungan Hidup RI No. 201 tahun 2004 tentang Kriteria Baku dan Pedoman Penentuan Kerusakan Mangrove sebagai acuan kondisi mangrove tersebut. Pengukuran dilakukan pada seluruh pohon yang berada di setiap plot. Identifikasi jenis dilakukan berdasarkan acuan Tomlinson (1986), Noor et al. (1999), Giesen et al. (2006), dan Kitamura et al. (1999). Apabila terjadi keraguan dalam identifikasi, perlu dilakukan pemotretan bagian tanaman tersebut, yaitu akar, batang, daun, pembungaan dan buah serta dilakukan pengambilan sampel untuk diidentifikasi lebih lanjut di laboratorium dengan bantuan literatur atau dengan bantuan pakar identifi kasi mangrove. Setiap data yang diperoleh dicatat dalam data sheet yang telah disiapkan pada kertas tahan air. Pencatatan data hasil pengukuran dilakukan berdasarkan data sheet yang ada.

\section{Pengukuran Persentase Penutupan Kanopi Mangrove}

Persentase tutupan mangrove dihitung dengan menggunakan metode hemisperichal photography, metode ini membutuhkan kamera yang memiliki resolusi baik (Jenning et al., 1999; Korhonen et al., 2006), selanjutnya untuk metode pengambilan gambar dan penentuan lokasi samppling mengikuti panduan dalam Dharmawan IWE dan Pramudji (2014).

\footnotetext{
Analisis Data

Identifikasi vegetasi mangrove menggunakan buku Kitamura, et al 1999 dan Noor, et al 2006.
}

Analisis vegetasi mangrove mempunyai tujuan untuk mendapatkan Indeks Nilai Penting (INP) yang merupakan penjumlahan dari frekuensi relatif, kerapatan relatif, dan dominansi relatif. Nilai penting suatu jenis berkisar antara 0 sampai 300 . Nilai penting ini memberikan gambaran mengenai pengaruh atau peranan suatu jenis tumbuhan mangrove dalam komunitas mangrove, untuk ketiga komponen INP tersebut dapat dihitung dengan rumus yang terdapat dalam Schaduw, (2015).

Analisis kerapatan mangrove dihitung untuk setiap jenis sebagai perbandingan dari jumlah individu suatu jenis dengan luas seluruh plot penelitian, kemudian dikonversi menjadi per satuan hektar. Nilai basal area (BA) juga dihitung dan nantinya digunakan sebagai acuan awal untuk melakukan penghitungan persentase tutupan mangrove. Untuk analisa persentase penutupan kanopi dilakukan dengan menggunakan software imajeJ (Dharmawan dan Pramudji, 2014)

\section{HASIL DAN PEMBAHASAN \\ Jenis Mangrove}

Jenis mangrove yang ditemukan pada lokasi penelitian sebanyak empat jenis, yaitu Rhizophora mucronata, Rhizophora apiculata, Bruguiera gymnorrhiza, dan Sonneratia alba. Stasiun 3 adalah stasiun yang memiliki keempat jenis mangrove tersebut, sedangkan stasiun 5 hanya memiliki dua jenis mangrove Rhizophora apiculata dan Bruguiera gymnorrhiza (Tabel 1). Stasiun lainnya hanya memiliki tiga jenis mangrove, stasiun 1 dan 2 memiliki jenis Rhizophora mucronata, Rhizophora apiculata dan Bruguiera gymnorrhiza, sedangkan stasiun 4 memiliki jenis mangrove Rhizophora apiculata, Bruguiera gymnorrhiza, dan Sonneratia alba. Kondisi ini hampir sama dengan jumlah jenis mangrove yang ada di sekitar Jembatan Suramadu Surabaya dengan jumlah 5 jenis (Susanto et al. 2013), mangrove Muara Gembong Kabupaten Bekasi 6 jenis (Rachmawati, et al., 2014), di pesisir Desa Kembar Maminasa jumlah 7 spesies (Rahman 2014) dan di Sungai Tallo sebanyak 3 jenis yakni Nypah fruticans, Rhizophora mucronata, dan Avicenia alba (Rahman, 2017). Hal ini berbeda dengan jenis mangrove yang ada Pulau Kaledupa, Jamili et al. (2009) menemukan jumlah jenis mangrove di perairan Pulau Keledupa Wakatobi berjumlah 8 jenis, sedangkan di perairan Desa Bambangan Pulau Sebatik terdapat 19 jenis (Ardiansyah et al. 2012). Penelitian mendalam dilakukan di Kecamatan Biduk Biduk, ditemukan 31 jenis mangrove yang terdiri atas 13 spesies mangrove sejati dan 18 spesies mangrove assosiasi (Prasetiyo et al. 2014), akan tetapi komposisi spesies mangrove di Kecamatan Biduk Biduk memiliki nilai yang cukup tinggi jika dibandingkan dengan daerah lainnya seperti di mangrove Pangkajene, Sulawesi Selatan (Ulumuddin \& Dharmawan, 2012). Hasil penelitian ini berbeda dengan penelitian lain yang dilakukan di kampung Teluk Sulaiman oleh Sudiono et al. (2013) yang 
mendapati 49 jenis mangrove dan terdiri atas 31 jenis mangrove sejati serta 18 jenis mangrove asosiasi. Pada daerah perlindungan lau (DPL) Blongko, mangrove menjadi salah satu ekosistem yang dilindungi, desa ini memiliki empat famili mangrove, dengan tujuh spesies. Famili mangrove tersebut adalah Avicenniaceae, Meliaceae, Rhizophoraceae, dan Sonneratiaceae. Sedangkan spesies mangrove yang ada di desa ini adalah Xylocarpus granatum, Avicennia lanata, Avicennia marina, Avicennia officinalis, Bruguiera gymnorrhiza, Rhizophora apiculata, dan Sonneratia alba (Schaduw, 2016) . Hal ini berbeda dengan DPL Desa Talise yang hanya memiliki dua famili mangrove yaitu Avicenniaceae dan Rhizophoraceae. Selain itu dari jumlah spesies Desa Talise hanya memiliki enam spesies diantaranya adalah Avicennia marina, Bruguiera cylindrica, Bruguiera gymnorrhiza, Rhizhopora apiculata, Rhizhopora mucronata, dan Rhizhopora stylosa (Wantasen, 2002). Pada pulau yang masuk kawasan konservasi Taman Nasional Bunaken, Pulau Mantehage adalah pulau dengan ekosistem mangrove terluas, pulau ini memiliki 8 jenis mangrove yang terdiri dari tiga famili. Jenis-jenis yang ada yaitu : Rhizophora apiculata, Rhizophora stylosa, Rhizophora mucronata, Bruguiera gymnorrhiza, Bruguiera cylindrical, Sonneratia alba, Ceriops tagal, Lumnitzera littorea, jenis-jenis mangrove tersebut termasuk dalam famili Rhizophoraceae, Sonneratiaceae, dan Combretaceae (Lahabu, et al. 2015). Keanekaragaman spesies cenderung rendah dalam ekosistem-ekosistem yang secara fisik dan kimia mendapat tekanan dan akan cenderung tinggi apabila dalam ekosistem diatur oleh alam dan kurang mendapat tekanan. Nilai keanekaragaman yang kecil terdapat pada daerah dengan lingkungan yang ekstrem, sedangkan nilai keanekaragaman yang sedang dan tinggi akan memberikan kesempatan terhadap masing-masing jenis untuk melangsungkan daur kehidupan yang lebih teratur, efisien, dan produktif (Resosoedarmo, et al. 1980). Dalam Tokuyama dan Arakaki (1988) disebutkan bahwa menurunnya keanekaragaman jenis pada ekosistem mangrove diakibatkan oleh perubahan fisik dan kimia ekosistem mangrove, akibatnya beberapa jenis mangrove mati dan terjadi dominasi pada jenis mangrove yang mampu bertahan pada situasi yang ekstrem ini.

Tabel 1. Jenis mangrove pada lokasi penelitian

\begin{tabular}{lccccc}
\hline JENIS & St. 1 & St. 2 & St. 3 & St. 4 & St.5 \\
MANGROVE & & & & & \\
\hline $\begin{array}{l}\text { Rhizophora } \\
\text { mucronata }\end{array}$ & $\mathrm{x}$ & $\mathrm{x}$ & $\mathrm{x}$ & & \\
$\begin{array}{l}\text { Rhizophora } \\
\text { apiculata }\end{array}$ & $\mathrm{x}$ & $\mathrm{x}$ & $\mathrm{x}$ & $\mathrm{x}$ & $\mathrm{x}$ \\
$\begin{array}{l}\text { Bruguiera } \\
\text { gymnorrhiza }\end{array}$ & $\mathrm{x}$ & $\mathrm{x}$ & $\mathrm{x}$ & $\mathrm{x}$ & $\mathrm{x}$ \\
\begin{tabular}{l} 
Sonneratia alba \\
\hline
\end{tabular} & & & $\mathrm{x}$ & $\mathrm{x}$ & \\
\hline
\end{tabular}

\section{Kerapatan mangrove}

Kerapatan mangrove pada Pulau Salawati bervariasi pada setiap stasiun pengamatan, kerapatan pohon teringgi terlihat pada stasiun 3 di Kampung Kolobo, di lokasi ini kerapatan mencapai 1600 pohon/ ha, diikuti Pulau Kasim Kecil (Stasiun 2) 1.450) pohon/ ha, Pulau Kabra Kecil 1.400 pohon/ha, Kampung Wamega 900 pohon/ha, dan terendah di Kampung Samate 867 pohon/ha (Gambar 2). Nilai ini lebih kecil dibandingkan nilai kerapatan mangrove di Segara Anakan yang mencapai 2.850 pohon/ha (Hilmi et al, 2015), tetapi nilai kerapatan mangrove di Pulau Salawati lebih besar dibandingkan Pulau Bunaken yaitu 740 pohon/ha (Schaduw, 2013; 2016). Kerapatan mangrove yang sangat padat juga ditemukan pada daerah Sungai Tallo di Makassar, hal ini dikarenakan variasi salinitas yang tinggi dan lingkungan yang sesuai dengan habitat mangrove (Rahman, 2017), sama halnya dengan daerah pesisir pantai Kecamatan Biduk-Biduk, Kalimantan Timur nilai kerapatan mangrove lebih dari 1.500 individu/ha (Prasetiyo et al., 2014). Kerapatan mangrove pada daerah Pemalang dan Rembang sangat dipengaruhi oleh salinitas, ketebalan lumpur, dan bahan organik (Poedjirahajoe, 2011). Kerapatan merupakan suatu indeks kepadatan individu dalam menguasai ruang atau areal yang menunjukan kualitas lingkungan pendukung pertumbuhan mangrove (Desmukh, 1992). Pola sebaran vegetasi melalui potensi kerapatan menunjukkan potensi penguasaan sumber hara oleh jenis vegetasi mangrove. Vegetasi mangrove yang memiliki kerapatan tertinggi berarti memiliki tingkat penguasaan hara yang terbesar (Ray et al, 2014 ; Tama et al,2009). Selain kaya akan unsur hara, daerah mangrove yang memiliki nilai kerapatan yang besar biasanya memiliki suplai air tawar yang baik, serta sedimen yang berpasir atau berlumpur. Tabel 2 memperlihatkan tipe substrat yang teramati pada lokasi penelitian adalah lumpur dan pasir berlumpur, kondisi ini sama dengan ekosistem mangrove daerah perlindungan laut Desa Blongko (Schaduw, 2015). Kerapatan pada suatu ekosistem mangrove berpengaruh pada biota yang berasosiasi di dalamnya . Dalam Skilleter and Warren (1999), ekosistem mangrove digunakan sebagai tempat perlindungan biota yang hidup di dalamnya seperti ikan dan moluska. Hal ini membuat ekosistem mangrove sering digunakan sebagai tempat memijah bagi berbagai organisme yang berasosiasi didalamnya. Hal ini dibuktikan Spitzer et al. (1999) yang menyatakan bahwa kepadatan makrofita mempengaruhi pertumbuhan ikan. Monitoring terhadap nilai kerapatan pada lokasi yang sama dapat menganalisa perubahan yang ada pada suatu ekosistem, penurunan nilai ini mengindikasikan adanya individu yang hilang akibat alam ataupun kegiatan antropogenik.

\section{Struktur Komunitas Mangrove}

Pulau Salawati memiliki struktur komunitas yang berbeda pada masing-masing stasiun pengamatan, 


\begin{tabular}{lcclll}
\hline & \multicolumn{3}{c}{ Tabel 2. lokasi stasiun, koordinat, tipe substrat dan kerapatan } \\
\cline { 2 - 3 } \multicolumn{1}{c}{ Nama Lokasi } & \multicolumn{2}{c}{ Koordinat } & Tipe Substrat & \multicolumn{2}{c}{ Kerapatan } \\
& Bujur & Lintang & & (Kepmen LH No. 201 thn 2004) \\
\hline KAMPUNG WAMEGA & 131.101 .800 & 1,00491 & Lumpur & Jarang \\
P.KASIM KECIL & 131.146 .330 & 1,00533 & Pasir Berlumpur & Sedang & Padat \\
KAMPUNG KALOBO & 131.074 .630 & 1,01217 & Pasir Berlumpur & Jarang \\
KAMPUNG SAMATE & 131.080 .640 & 0,97307 & Lumpur & Jar & Sedang \\
P. KABRA KECIL & 131.157 .520 & 1,07776 & Lumpur & \\
\hline
\end{tabular}

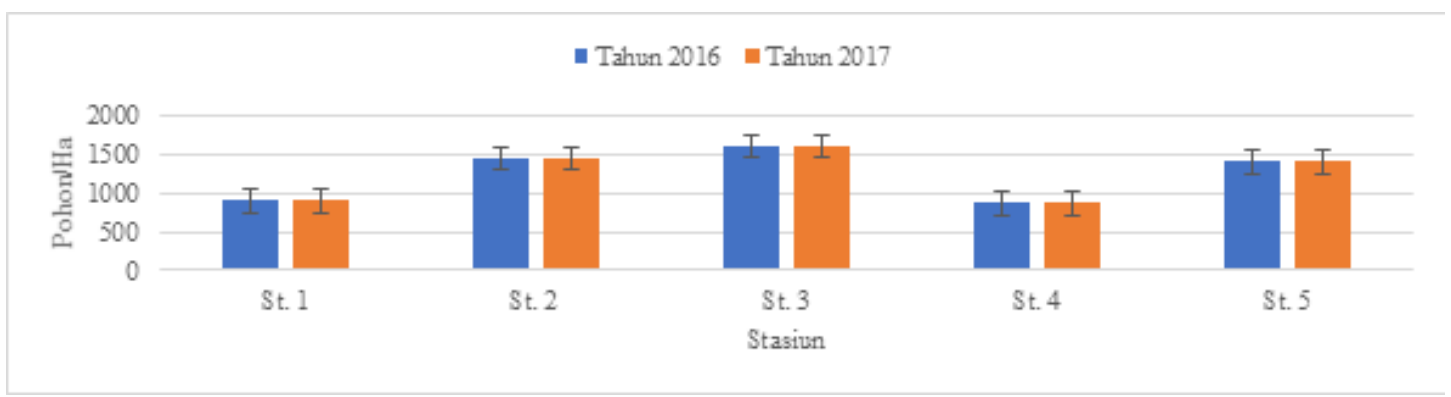

Gambar 2. Kerapatan mangrove masing-masing stasiun

kajian struktur komunitas akan membahas frekuensi, kerapatan, penutupan, dan indeks nilai penting (INP) dari masing-masing spesies pada setiap stasiun pengamatan. Menurut Bengen (2003) nilai penting digunakan untuk melihat pertumbuhan jenis mangrove dalam suatu komunitas, dapat dilihat dari analisis kondisi vegetasi yang menunjukkan peranan suatu jenis mangrove dalam komunitas mangrove. Nilai penting dari tiap jenis mangrove sangat tergantung kondisi pertumbuhan mangrove. Mangrove untuk tumbuh dengan baik, memerlukan sejumlah faktor pendukung seperti ketersediaan nutrient atau bahan organik, substrat yang cocok, kondisi perairan yang stabil dan tidak adanya ekspolitasi mangrove oleh masyarakat setempat. Untuk nilai frekuensi dan kerapatan tahun 2016 dan 2017 tidak memiliki perbedaan, hal ini mengindikasikan tidak ada pohon yang tumbang dalam kurun waktu satu tahun pada lokasi pengamatan. Stasiun 1 memiliki nilai frekuensi yang sama pada setiap jenisnya, sedangkan untuk kerapatan relatif jenis tertinggi terlihat pada jenis Rhizophora apiculata $(37,04 \%)$ dan terendah jenis Bruguiera gymnorrhiza (29,63\%). Untuk penutupan relatif tertinggi pada stasiun 1 adalah jenis Rhizophora apiculata $(55,44 \%)$ dan terendah jenis Rhizophora mucronata $(9,47 \%)$ sedangkan untuk indeks nilai penting tertinggi pada jenis Rhizophora apiculata $(125,8 \%)$ dan terendah jenis Rhizophora mucronata $(76,13 \%)$. Indeks nilai penting jenis mangrove stasiun 1,2, dan 3 yang tertinggi pada jenis Rhizophora apiculata dan terendah pada jenis Rhizophora mucronata, Stasiun 4 untuk INP tertinggi pada jenis Rhizophora apiculata dan terendah pada jenis Sonneratia alba, berbeda dengan stasiun 5 untuk INP tertinggi jenis Bruguiera gymnorrhiza dan terendah jenis Rhizophora apiculata, selanjutnya untuk nilai
INP masing-masing stasiun dapat dilihat pada Tabel 3. Secara keseluruhan indeks nilai penting mangrove Pulau Salawati tertinggi pada jenis Rhizophora apiculata dan terendah pada jenis Sonneratia alba (Tabel 4), Kondisi INP masing-masing jenis ini sama dengan ekosistem mangrove di Kecamatan Biduk-biduk (Prasetiyo, 2014). Pada ekosistem mangrove disepanjang pesisir bagian utara Taman Nasional Bunaken INP mangrove tertinggi jenis Sonneratia alba dan terendah jenis Rhizophora mucronata (Anthoni et al, 2017), sedangkan Taman Wisata Alam Laut Teluk Kupang jenis mangrove dengan INP tertinggi adalah Rhizophora stylosa dan terendah jenis Xylocarpus granatum (Bessie, 2013), Sasauw (2013) melalui kajiannya di Desa Tongkaina Kota Manado INP mangrove tertinggi jenis Rhizophora apiculata dan terendah Sonneratia alba. Ekosistem mangrove juga termasuk dalam kawasan konservasi, sebagai contoh INP mangrove di daerah perlindungan laut (DPL) Desa Blongko tertinggi jenis Sonneratia alba dan terendah Xylocarpus granatum (Schaduw, 2015), sedangkan untuk Pulau Mantehage yang berada dalam kawasan Taman Nasional Bunaken INP tertinggi jenis Rhizophora apiculata dan terendah Rhizophora stylosa (Lahabu et al, 2015). Ekosistem mangrove yang berada di kawasan teluk dan muara sungai memiliki karakteristik substrat yang didominasi oleh liat serta memiliki masukan air tawar yang melimpah. Kondisi tersebut memberikan kontribusi besar terhadap dominansi spesies Rhizophora apiculata di wilayah teluk dan muara. Secara ekologi spesies Rhizophora apiculata lebih dapat beradaptasi pada lingkungan yang bersubstrat lumpur dan cenderung menghindari lingkungan dengan substrat yang mengandung pasir ataupun substrat yang lebih keras. (Noor et al., 2006; Setyawan dan Ulumuddin, 2012). Giesen (2006) 
berpendapat spesies Sonneratia alba merupakan jenis mangrove yang sering tumbuh pada daerah berpasir bahkan dapat juga tumbuh pada daerah berbatu, dan seringkali spesies Sonneratia alba menjadi spesies yang dominan pada zona pasang surut pesisir. Spesies ini biasanya menjadi spesies yang dominan di daerah intertidal bawah bersama dengan spesies lain seperti Avicenia marina serta dapat tumbuh sampai memiliki ketinggian 30m. Karakteristik spasial ekosistem mangrove sangat dipengaruhi oleh salinitas, suhu, $\mathrm{pH}$, jenis subsrat, kandungan oksigen dan ketebalan lumpur, kajian pada ekosistem mangrove di Pantai
Utara Pemalang membentuk tiga cluster dengan karakteristik habitat yang berbeda (Poedjirahajoe, 2017). Perbedaan nilai INP Pulau Salawati tahun 2016 dan 2017 dipengaruhi oleh pertumbuhan mangrove pada keliling lingkar pohon bertambah $2-3 \mathrm{~cm} /$ tahun yang mempengaruhi penutupan relatif dan INP (Tabel 3). Karakteristik spasial ekosistem mangrove sangat dipengaruhi oleh Salinitas, suhu, $\mathrm{pH}$, jenis subsrat, kandungan oksigen dan ketebalan lumpur, kajian pada ekosistem mangrove di Pantai Utara Pemalang membentuk tiga cluster dengan karakteristik habitat yang berbeda (Poedjirahajoe, 2017).

Tabel 3. Struktur Komunitas Mangrove Masing-Masing Stasiun

\begin{tabular}{|c|c|c|c|c|c|c|c|c|}
\hline \multirow[t]{2}{*}{ Stasiun } & \multirow[t]{2}{*}{ Jenis } & \multicolumn{7}{|c|}{2016} \\
\hline & & $\mathrm{F}$ & $\mathrm{D}$ & $\mathrm{C}$ & FR & DR & $\mathrm{CR}$ & INP \\
\hline \multirow[t]{3}{*}{ St.1 } & Rhizophora mucronata & 1 & 9 & 1361 & 33,33 & 33,33 & 9,47 & 76,13 \\
\hline & Rhizophora apiculata & 1 & 10 & 7969,02 & 33,33 & 37,04 & 55,44 & 125,8 \\
\hline & Bruguiera gymnorrhiza & 1 & 8 & 5045,09 & 33,33 & 29,63 & 35,09 & 98,07 \\
\hline \multirow[t]{3}{*}{ St. 2} & Rhizophora mucronata & 0,25 & 4 & 2127,44 & 11,12 & 7,28 & 10,92 & 29,3 \\
\hline & Rhizophora apiculata & 1 & 34 & 14619,3 & 44,44 & 61,81 & 75,07 & 181,33 \\
\hline & Bruguiera gymnorrhiza & 1 & 17 & 2727,06 & 44,44 & 30,91 & 14,01 & 89,35 \\
\hline \multirow[t]{4}{*}{ st. 3} & Rhizophora mucronata & 0,33 & 5 & 1437,55 & 12,5 & 10,41 & 9,43 & 32,35 \\
\hline & Rhizophora apiculata & 1 & 33 & 10863,6 & 37,5 & 68,75 & 71,31 & 177,56 \\
\hline & Bruguiera gymnorrhiza & 0,67 & 5 & 1557,1 & 25 & 10,42 & 10,23 & 45,63 \\
\hline & Sonneratia alba & 0,66 & 5 & 1374,94 & 25 & 10,42 & 9,03 & 44,44 \\
\hline \multirow[t]{3}{*}{ St.4 } & Rhizophora apiculata & 1 & 16 & 13004,6 & 42,85 & 61,64 & 89,28 & 193,68 \\
\hline & Bruguiera gymnorrhiza & 1 & 8 & 1348,06 & 42,86 & 30,76 & 9,26 & 82,89 \\
\hline & Sonneratia alba & 0,333 & 2 & 211,91 & 14,28 & 7,69 & 1,455 & 23,43 \\
\hline \multirow[t]{2}{*}{ St. 5} & Rhizophora apiculata & 0,833 & 14 & 5097,51 & 45,45 & 16,67 & 16,12 & 78,24 \\
\hline & Bruguiera gymnorrhiza & 1 & 70 & 26515,3 & 54,54 & 83,33 & 83,87 & 221,75 \\
\hline \multirow[t]{2}{*}{ Stasiun } & Jenis & \multicolumn{7}{|c|}{2017} \\
\hline & & $\mathrm{F}$ & $\mathrm{D}$ & $\mathrm{C}$ & FR & DR & CR & INP \\
\hline \multirow[t]{3}{*}{ St.1 } & Rhizophora mucronata & 1 & 9 & 1396,5 & 33,33 & 33,33 & 9,59 & 76,26 \\
\hline & Rhizophora apiculata & 1 & 10 & 8068,14 & 33,33 & 37,04 & 55,45 & 125,82 \\
\hline & Bruguiera gymnorrhiza & 1 & 8 & 5083,83 & 33,33 & 29,63 & 34,94 & 97,91 \\
\hline \multirow[t]{3}{*}{ St. 2} & Rhizophora mucronata & 0,25 & 4 & 2153,53 & 11,12 & 7,28 & 10,85 & 29,24 \\
\hline & Rhizophora apiculata & 1 & 34 & 14899,3 & 44,44 & 61,81 & 75,12 & 181,38 \\
\hline & Bruguiera gymnorrhiza & 1 & 17 & 2780,51 & 44,44 & 30,91 & 14,01 & 89,37 \\
\hline \multirow[t]{4}{*}{ st.3 } & Rhizophora mucronata & 0,33 & 5 & 1481,38 & 12,5 & 10,41 & 9,47 & 32,38 \\
\hline & Rhizophora apiculata & 1 & 33 & 11161,4 & 37,5 & 68,75 & 71,35 & 177,6 \\
\hline & Bruguiera gymnorrhiza & 0,67 & 5 & 1579,7 & 25 & 10,42 & 10,09 & 45,51 \\
\hline & Sonneratia alba & 0,66 & 5 & 1419,73 & 25 & 10,42 & 9,07 & 44,49 \\
\hline \multirow[t]{3}{*}{ St.4 } & Rhizophora apiculata & 1 & 16 & 13265,6 & 42,85 & 61,64 & 89,3 & 193,7 \\
\hline & Bruguiera gymnorrhiza & 1 & 8 & 1371,2 & 42,86 & 30,76 & 9,23 & 82,85 \\
\hline & Sonneratia alba & 0,333 & 2 & 216,76 & 14,28 & 7,69 & 1,46 & 23,43 \\
\hline \multirow[t]{2}{*}{ St.5 } & Rhizophora apiculata & 0,833 & 14 & 5188,51 & 45,45 & 16,67 & 16,16 & 78,28 \\
\hline & Bruguiera gymnorrhiza & 1 & 70 & 26903 & 54,54 & 83,33 & 83,83 & 221,71 \\
\hline
\end{tabular}


Joshian Nicolas William Schaduw /Majalah Geografi Indonesia, Vol. 33 No.1, Maret 2019 : 26 - 34

Tabel. 4 Struktur komunitas mangrove masing-masing jenis

\begin{tabular}{|c|c|c|c|c|c|c|c|}
\hline \multirow[t]{2}{*}{ Jenis } & \multicolumn{7}{|c|}{ Tahun 2016} \\
\hline & $\Sigma \mathrm{F}$ & $\Sigma \mathrm{D}$ & $\Sigma \mathrm{C}$ & $\Sigma \mathrm{FR}$ & $\Sigma \mathrm{DR}$ & $\Sigma \mathrm{CR}$ & $\Sigma$ INP \\
\hline Rhizophora mucronata & 1,58 & 18,00 & 4925,99 & 56,95 & 51,02 & 29,82 & 137,78 \\
\hline Rhizophora apiculata & 3,83 & 74,00 & 40690,43 & 166,07 & 177,16 & 235,91 & 579,05 \\
\hline Bruguiera gymnorrhiza & 4,67 & 108,00 & 37192,61 & 200,17 & 185,05 & 152,46 & 537,69 \\
\hline Sonneratia alba & 0,99 & 7,00 & 1586,85 & 39,28 & 18,11 & 10,49 & 67,87 \\
\hline \multirow[t]{2}{*}{ Jenis } & \multicolumn{7}{|c|}{ Tahun 2017} \\
\hline & $\sum \mathrm{F}$ & $\Sigma \mathrm{D}$ & $\Sigma \mathrm{C}$ & $\Sigma \mathrm{FR}$ & $\Sigma \mathrm{DR}$ & $\Sigma \mathrm{CR}$ & $\sum$ INP \\
\hline Rhizophora mucronata & 1,58 & 18,00 & 5031,41 & 56,95 & 51,02 & 29,91 & 137,88 \\
\hline Rhizophora apiculata & 3,83 & 74,00 & 41421,55 & 166,07 & 177,16 & 236,03 & 579,18 \\
\hline Bruguiera gymnorrhiza & 4,67 & 108,00 & 37718,24 & 200,17 & 185,05 & 152,10 & 537,35 \\
\hline Sonneratia alba & 0,99 & 7,00 & 1636,49 & 39,28 & 18,11 & 10,53 & 67,92 \\
\hline
\end{tabular}

\section{Persentase Penutupan Kanopi Mangrove}

Persentase penutupan kanopi mangrove pada Pulau Salawati tahun 2016 berkisar antara 81,16\% - 87,02\%, presentasi penutupan kanopi mangrove tertinggi pada Stasiun $3(87,02 \%)$, diikuti stasiun 4 (86,38\%), Stasiun 5 $(84,68 \%)$, Stasiun $1(81,46 \%)$, dan yang terendah stasiun $2(81,46 \%)$ (Tabel 5), persentase kanopi mangrove tahun 2017 mengalami sedikit perubahan, pada stasiun 2,3,4, dan 5 mengalami peningkatan 1,15\% - 3,53\%, sedangkan pada stasiun 1 terjadi penurunan persentase penutupan kanopi sebesar 8,62\% (Gambar 3). Secara keseluruhan persentase rata-rata penutupan kanopi Pulau Salawati tahun $2016(84,14 \%)$ naik 0,59\% ditahun 2017 $(84,73 \%)$ (Gambar 4). Persentase penutupan mangrove pada tahun 2017 lebih tinggi dibandingkan tahun sebelumnya hal ini mengindikasikan pertumbuhan mangrove pada lokasi penelitian cukup baik, dan dapat dikatakan tidak terjadi degradasi yang signifikan pada lokasi penelitian. Pada stasiun 1 data tahun 2017 mengindikasikan terjadinya penurunan persentase penutupan mangove sebesar $8,62 \%$, penurunan ini terjadi akibat dari penebangan pohon mangrove di sekitar plot pengamatan, yang mengakibatkan robohnya pohon dan menimpa cabang/ranting mangrove dalam lokasi pengamatan. Persentase tutupan mangrove Taman Nasional Perairan (TNP) Laut Sawu termasuk dalam kategori baik dengan persentase tutupan sebesar $78,17 \pm 11,41 \%$. Sebagian besar kawasan didominasi oleh Sonneratia alba, yang mampu beradaptasi dengan baik pada substrat berpasir dan salinitas yang tinggi (Giyanto et al 2015), hal ini lebih kecil dibandingkan persentase tutupan mangrove Kabupaten Kepulauan Mentawai $69.14 \pm 6.00 \%$ (Siringoringo et al 2014). Kajian Suharsono et al (2014) dimuara Sungai Kawal persentase penutupan mangrove mencapai $75.07 \pm$ $7.07 \%$ dengan kerapatan $1188.89 \pm 483.33$ pohon/ha, sedangkan Manuputty et al (2014) melalui kajiannya di Pulau Buli persentase tutupan kanopi mangrove berkisar antara $92.80 \pm 2.16 \%$ dan $58.19 \pm 12.16 \%$.
Tabel 5. Persentse penutupan dan kerapatan mangrove

\begin{tabular}{lllll}
\hline St & Lokasi Stasiun & $\begin{array}{l}\text { \%cover } \\
(2016)\end{array}$ & $\begin{array}{l}\text { \%cover } \\
(2017)\end{array}$ & Selisih \\
\hline 1 & KAMPUNG & $81,46 \pm$ & $72,83 \pm$ & $-8,62$ \\
& WAMEGA & 6,27 & 11,23 \\
2 & P.KASIM & $81,16 \pm$ & $84,67 \pm$ & 3,51 \\
& KECIL & 2,14 & 5,303 \\
3 & KAMPUNG & $87,02 \pm$ & $90,54 \pm$ & 3,53 \\
& KALOBO & 3,58 & 1,503 \\
4 & KAMPUNG & $86,38 \pm$ & $89,74 \pm$ & 3,37 \\
& SAMATE & 2,99 & 3,487 \\
5 & P. KABRA & $84,68 \pm$ & 85,82 \\
& & 3,90 & $\pm 10,21$ \\
\hline
\end{tabular}
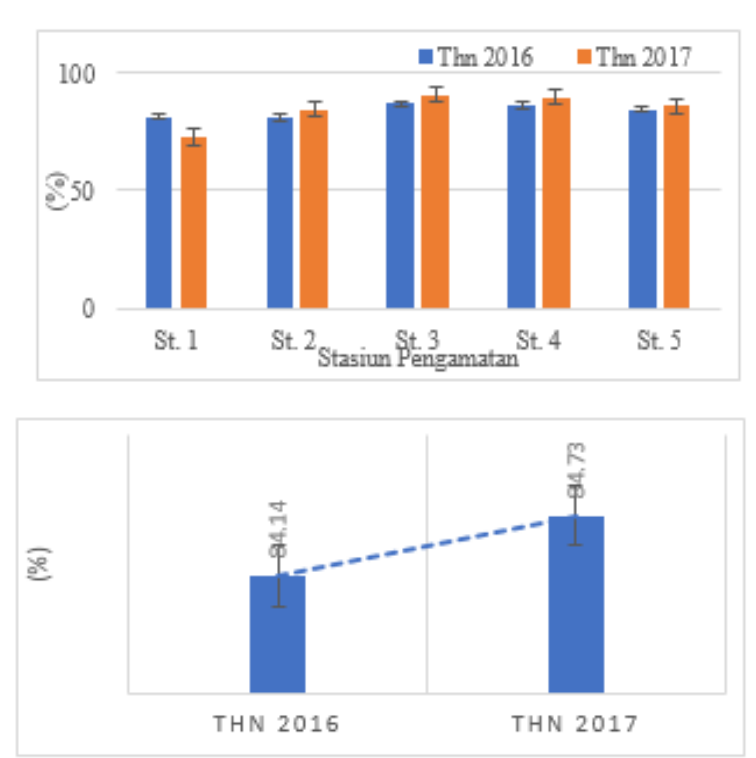

Gambar 3. Persentase dan Rata-Rata Penutupan Kanopi Mangrove Pulau Salawati

\section{KESIMPULAN}

Mangrove yang ada di Pulau Salawati berjumlah empat jenis yaitu Rhizophora mucronata, Rhizophora apiculata, Bruguiera gymnorrhiza, dan Sonneratia alba. 
Kerapatan rata-rata mangrove di Pulau Salawati sebesar 1254,3 ind/ha, hal ini masuk dalam kategori padat. Kondisi kanopi mangrove Pulau Salawati termasuk kategori baik dengan nilai rata-rata persentase penutupan kanopi sebesar $84,73 \%$ (tahun 2017) dengan kenaikan nilai persentase dalam satu tahun $0,59 \%$. Indeks nilai penting tertinggi mangrove yang ada di Pulau Salawati adalah jenis Rhizophora apiculata dan terendah jenis Sonneratia alba. Stasiun 1 di Kampung Wamwga terindikasi adanya penebangan pohon disekitar plot pengamatan sehingga menurunkan nilai persentase kanopi, akan tetapi hal ini tidak mempengaruhi nilai kerapatan karena berada diluar plot pengamatan permanen. Dari hasil kajian ini maka perlu dilakukan monitoring dan evaluasi secara berkala untuk menjaga ekosistem ini dari aktivitas manusia yang bersifat merusak dan gejala alam lainnya.

\section{UCAPAN TERIMA KASIH}

Penulis mengucapkan terima kasih kepada COREMAP-CTI Pusat Penelitian Oseanografi, Lembaga Ilmu Pengetahuan Indonesia (LIPI) yang memberikan dana untuk melakukan kajian secara berkala. Hal yang sama juga ditujukan kepada Kementerian Riset Teknologi dan Pendidikan Tinggi Lembaga Penelitian dan Pengabdian pada Masyarakat (LPPM) Universitas Sam Ratulangi dan Dekan Fakultas Perikanan dan Ilmu Kelautan Universitas Sam Ratulangi yang telah banyak membantu memfasilitasi kajian ini.

\section{DAFTAR PUSTAKA}

Alongi DM, Trott LA, Wattayakorn G, Clough F. (2002). Below-Ground Nitrogen Cycling In Relation to Net Canopy Production in Mangrove Forests Of Southern Thailand. Marine Biology 140: 855-864 Anthoni A, Joshian NWS, Calvyn FAS. (2017). Persentase Tutupan Dan Struktur Komunitas Mangrove Di Sepanjang Pesisir Taman Nasional Bunaken Bagian Utara, Jurnal Pesisir dan Laut Tropis. 2 (1): 13-21

Ardiansyah WI, Rudhi P, Nirwani S. (2012). Struktur komposisi dan vegetasi ekosistem mangrove di Kawasan Pesisir Pulau Sebatik Kabupaten Nunukan, Kalimantan Timur. Journal of Marine Research 1:203-215.

Ashton EC \& DJ Macintosh. (2002). Preliminary assessment of the plant diversity and community ecology of the Sematan mangrove forest, Sarawak, Malaysia. Forest Ecology and Management. 166: 111-129.

Bengen DG. (2003). Teknik Pengambilan Contoh dan Analisis Data Biofisik Sumberdaya Peisisir - Sinopsis. Pusat Kajian Sumberdaya Pesisir dan Lautan IPB. Bogor.

Bessie DM, Joshian NWS, Emil R \& Markus TL. (2013). Community structure of mangrove at Marine Tourism Park of Kupang Bay, East Nusa Tenggara Aquatic Science \& Management, Edisi Khusus 1 : 3-9

Desmukh.(1992). Ekologi dan Biologi Tropika. Yayasan Obor Indonesia, Jakarta.

Dharmawan IWE \& Pramudji. (2014). Panduan Monitoring Status Ekosistem Mangrove. COREMAP-CTI-LIPI.

English S, Wilkinson C \& Baker V. (1997). Survey Manual for Tropical Marine Resources. 2nd edition. Australian Institute of Marine Science. Townsville.
FAO. (2007). The World's Mangroves 1980-2005. Forest Resources Assessment Working Paper No. 153. Food and Agriculture Organization of The United Nations. Rome.

Giesen W, Wulffraat S, Zieren M \& Scholten L. (2006). Mangrove Guidebook for Southeast Asia. FAO and Wetlands International. Bangkok. Giyanto, Kiswara W, Suyarso, Edrus IN, Dharmawan IWE, Utama RS, Budiyanto A, Salatalohy A, Unyang S, Pratama KY \& Lapon Y. (2015). Monitoring Kesehatan Terumbu Karang dan Ekosistem Terkait di Taman Nasional Perairan Laut Sawu Tahun 2015 (Baseline). COREMAPCTI. Pusat Penelitian Oseanografi-LIPI. Jakarta. Grasso M. (1998). Ecological-economic model for optimal mangrovetradeoffbetweenforestryandfisheryproduction: comparing a dynamic optimization and a simulation model. Ecological Modelling 112 (1998) 131-150

Hilmi E, Asrul SS, Luvianna F, Rima N, Sya'bani AA \& Agung DS. (2015). Struktur Komunitas, Zonasi Dan Keanekaragaman Hayati Vegetasi Mangrove Di Segara Anakan Cilacap. OmniAkuatika, 11 (2): 20-32

Holmer M \& Olsen AB. (2002). Role of decomposition of mangrove and seagrass detritus in sediment carbon and nitrogen cycling in a tropical mangrove forest. Mar. Ecol. Prog. Ser. 230: 87-101

Jamili, Dede S, Ibnul Q \& Edi G. (2009). Struktur dan komposisi mangrove di Pulau Kaledupa Taman Nasional Wakatobi, Sulawesi Tenggara. Skripsi (Tidak dipublikasikan). Universitas Haluoleo, Kendari. Jenning SB, Brown ND \& Sheil D. (1999). Assessing forest canopies and understorey illumination: canopy closure, canopy cover and other measures. Forestry 72(1): 59-74.

Kitamura S, Anwar C, Chaniago A \& Baba S. (1999). Handbook of Mangroves in Indonesia. Saritaksu. Denpasar.

Korhonen L, Korhonen KT, Rautiainen M \& Stenberg P. (2006). Estimation of forest canopy cover: a comparison of field measurement techniques. Silva Fennica 40(4): 577-588.

Komiyama A, Ong JE \& Poungparn S. (2008). Allometry, biomass and productivity of mangrove forest: A review. Aquatic Botany 89:128-137.

Lahabu Y, Joshian NWS \& Agung BW. (2015). Kondisi Ekologi Mangrove Di Pulau Mantehage Kecamatan Wori Kabupaten Minahasa Utara Provinsi Sulawesi Utara, Jurnal Pesisir dan Laut Tropis. 2(1) 41-52

Manuputty AEW, Frensly DH, Hendrik AWC, Jemmy S, Suyarso, Agus B, I Wayan ED, Ernawati W \& Susi R. (2014). Monitoring Kesehatan Terumbu Karang dan Kesehatan Ekosistem Terkait di Kabupaten Lingga. COREMAPCTI. Pusat Penelitian Oseanografi-LIPI. Jakarta. Nagelkerken I \& Van Der Velde G. (2004). Are Caribbean Mangroves Important Feeding Grounds For Juvenile Reef Fish From Adjacent Seagrass Beds. Mar. Ecol. Prog. Ser. 274: 143-151.

Noor YR, Khazali M \& Suryadiputra INN. (2006). Panduan Pengenalan Mangrove di Indonesia. Wetland International, Bogor.

Poedjirahajoe E. (2007). Dendogram Zonasi Pertumbuhan Mangrove Berdasarkan Habitatnya di kawasan rehabilitasi pantai utara jawa tengah bagian barat. Jurnal Ilmu Kehutanan 1 (2) : 10-21

Poedjirahajoe E, Ragil W \& Ni Putu Diana M. (2011). Kajian Ekosistem Mangrovehasil rehabilitasipadaberbagaitahun tanam untuk estimasi kandungan ekstrak tanin di pantai utara jawa tengah. Jurnal Ilmu Kehutanan 5 (2) : 99-107

Poedjirahajoe E. (2015). Klasifikasi habitat mangrove untuk pengembangan silvofishery kepiting 
soka (scylla serrata) di pantai utara kabupaten rembang. Jurnal Ilmu Kehutanan 9 (2) : 85-93

Poedjirahajoe E, Djoko M \& Frita Kusuma W. (2017). Penggunaan Principal Component Analysis dalam Distribusi Spasial Vegetasi Mangrove di Pantai Utara Pemalang. Jurnal Ilmu Kehutanan 11 : 29-42

Prasetiyo, DandyE, Ferbrian K, Atmanegara, Firman Z, HaniSP, Achmad S, Anisa B \& Edy S. (2014). Kajian sosio-ekologis kawasan mangrove di pesisir pantai kecamatan bidukbiduk, kalimantan timur. Omni-Akuatika 8 (18): 1 - 9

Rachmawati D, Isdradjad S \& Endang H. (2014). Potensi Estimasi Karbon Tersimpan Pada Vegetasi Mangrove Di Wilayah Pesisir Muara Gembong Kabupaten Bekasi. Omni-Akuatika 8(19): 85 - 91

Rahman. (2014). Struktur komunitas mangrove berdasarkan perbedaan substrat di Desa Kembar Maminasa Kecamatan Maginti, Kabupaten Muna.Skripsi(Tidakdipublikasikan). Universitas

Hasanuddin,Makassar.

Rahman, Hefni E \& Iman R. (2017). Estimasi Stok dan Serapan Karbon pada Mangrove di Sungai Tallo, Makassar. Jurnal Ilmu Kehutanan. 11:19-28

Ray RN, Majumder, Chowdhury C \& Jana TK. (2014). Biogeochemical cycle of nitrogen in a tropical mangrove ecosystem, eastcoastofIndia.MarineChemistry 167:33-43

Resosoedarmo RS, Kartawinata K, Soegiarto A. 1980. Pengantar Ekologi. C.V. Remadja Karya. Cetakan I. Bandung.

Sasauw J, Janny DK \& Joshian NWS. (2016). Struktur Komunitas Mangrove Di Kelurahan Tongkaina Manado. Jurnal Pesisir dan Laut Tropis. 2 (1) :17-22

Schaduw JNW. (2013). Small island mitigation based on mangrove ecosystem management in Bunaken National Park. Aquatic Science \& Management 1 (2), 133-142

Schaduw JNW. (2015). Bioekologi Mangrove Daerah Perlindungan Laut Berbasis Masyarakat Desa Blongko Kecamatan Sinonsayang Kabupaten Minsel Provinsi Sulut. Jurnal LPPM UNSRAT bidang Sains dan Teknologi 2 (1): 89-102

Schaduw JNW. (2016). Kondisi Ekologi Mangrove Pulau Bunaken Kota Manado Provinsi Sulawesi Utara. Jurnal LPPM UNSRAT bidang Sains dan Teknologi. 3 (2):65-74

Setiawan H. (2013). Akumulasi dan distribusi logam berat pada vegetasi mangrove di Perairan pesisir sulawesi selatan. Jurnal Ilmu Kehutanan 7 (1) : 12-24

Siringoringo RM, Rizkie SM, Abrar BH, Kunto W, Ucu A, Mudjiono, Wayan E, Susi R\&Sutiadi R.(2014). Monitoring Kesehatan Terumbu Karang Dan Kesehatan Ekosistem Terkait Di Kabupaten Kepulauan Mentawai. COREMAP-
CTI. Pusat Penelitian Oseanografi-LIPI. Jakarta. Skilleter GA \& Warren S. (1999). Effects of Habitat Modification in Mangroves on the Structure of Mollusc \& Crab Assemblages. Elsevier. 244 : 107-129 Spitzer PM, Mattila J \& Heck JrKL. (1999). The Effects of Vegetation Density on the Relative Growth Rates of Juvenile Pinfish, Lagodon rhomboides (Linneaus), in Big Lagoon, Florida. Elsevier. 244 :67-86 Sudiono E, Sasmirul A, Purwnomo, Jasari, Sujoko, U \& Sahri A. (2013). Laporan Survey Biodiversitas Kawasan Mangrove Teluk Sulaiman dan Tata Batas kawasan Lindung dan Wisata Alam Labuan Cermin, kecamatan Biduk-Biduk, Kabupaten Berau (Laporan Internal). The Nature Conservancy. Berau. Suharsono S, Anna EWM, Hendrik AWC, Suyarso, Agus B, Johan P, Priti S, I Wayan ED \& Susi R. (2014). Monitoring kesehatan terumbu karang dan kesehatan ekosistem terkait di kabupaten bintan. COREMAPCTI. Pusat Penelitian Oseanografi-LIPI. Jakarta. Susanto AH, Thin S \& Hery P. (2013). Struktur komunitas mangrove di sekitar Jembatan Suramadu sisi Surabaya. Skripsi (Tidak dipublikasikan): Universitas Airlangga, Surabaya. Tama NFY, Wonga AHY, Wong MH \& Wong YS. (2009). Mass Balance Of Nitrogen In Constructed Mangrove Wetlands Receiving Ammonium-Rich Wastewater: Effects Of Tidal Regime And Carbon Supply. Ecological Engineering 3 (5 ):453-462 Tokuyama A \& Arakaki T. (1988). Physical and Chemical Study of The Causes of Mangrove Death Along The Nakama River. Iriomote Island. Okinawa. Galaxea. 7:271-286.

Tomlinson PB. (1986). The Botany of mangroves. Cambridge University Press, Cambridge, UK.

Ulumuddin YI \& Darmawan IWE. (2012). Keanekaragaman Tumbuhan, Ekologi Komunitas, dan Stok Karbon: Pentingnya Mangrove di Pulau-Pulau Kecil Kabupaten Pangkajene Kepulauan, Sulawesi Selatan. Lembaga Ilmu Pengetahuan Indonesia. Jakarta. Wantasen, A. (2002). Kajian Ekonomi - Ekologi Ekosistem Mangrove Daerah Perlindungan Laut Desa Talise, Kabupaten Minahasa, Sulawesi Utara. Tesis (Tidak Dipublikasikan). Program Pascasarjana, Institut Pertanian Bogor. 